\title{
Gatunkowa hybryda z 1638 roku: Samuela Twardowskiego „Dafnis drzewem bobkowym" (przyczynek do „zagłady gatunków")
}

Krzysztof Obremski 


\section{Interpretacje}

Gatunkowa hybryda z 1638 roku:

Samuela Twardowskiego

Dafnis drzewem bobkowym

(przyczynek do „zagłady gatunków")

Krzysztof Obremski

TEKSTY DRUGIE 2017, NR 6, S. 142-165

DOI: $10.18318 /$ td.2017.6.8

W kontekście staropolskiej kultury literackiej wstępne pytanie brzmi: Dafnis drzewem bobkowym byłaby „hybrydą” czy „sylwą"? Ściślej pytając: jaką sylwą? Szlachecką (raptularzową) czy tą w rozumieniu genologicznym? Wszak ich przeciwstawienia zignorować niepodobna'. Za „hybrydą" i tym samym przeciwko "sylwie" w rozumieniu genologicznym najogólniej przemawia to, że według autora traktatu $O$ poezji doskonałej tę drugą charakteryzuje „obfitość i mnogość

1 "[...] sylwy szlacheckie i sylwy w rozumieniu genologicznym, obejmujące spowinowacone retoryczną genezą gatunki poetyckie, które nawiązywały w mniej lub bardziej wierny sposób do zbioru Stacjusza [pięciotomowych Sylw], to zjawiska nietożsame. Poza nazwą niewiele je łączy. [...] Zbyt pochopne kojarzenie odrębnych zjawisk należących do literatury dawnej i konstruowanie spójnej koncepcji wynikającej z uwzględnienia ich cech swoistych, jakkolwiek prowadzić może do całkiem interesujących, a nawet prawdziwych twierdzeń na temat kultury XX-wiecznej i najnowszej, zdaje się jednak zanadto fałszować naturę tych zjawisk". R. Krzywy Silvae i sylwy - glosa historycznoliteracka do pewnego nieporozumienia, "Pamiętnik Literacki" 2013 Z. 3, s. 151.
Krzysztof

Obremski - prof.

dr hab., pracuje

w Zakładzie Literatury

Staropolskiej (Insty-

tut Literatury Polskiej

UMK). Główne

zainteresowania ba-

dawcze: nurt religijny

literatury staropol-

skiej, sarmatyzm,

teoria i praktyka reto-

ryczna (szczególnie

panegiryk i panegi-

ryzm), współczesna

humanistyka w in-

terpretacji literatury

staropolskiej. 
poruszanych tematów" - jedność fabuły nie jest respektowana². Tymczasem Dafnidzie owej jedności fabuły, czy przynajmniej spójności, niepodobna odmówić. Co więcej: za "hybrydą” przemawia również to, że znamienna dla antycznych utworów lirycznych o charakterze okolicznościowym różnorodność tematyczna (najkrócej: od narodzin człowieka aż po śmierć) z czasem stanie się tak ekspansywna, że dziś można mówić o sylwach współczesnych ${ }^{3}$.

Jeśli nawet Dafnidę można byłoby czytać jako utwór sylwiczny, to jednak nie za sprawą znamiennej różnorodności tematycznej (wszak ów tekst z 1638 roku pozostał jednorodny w swojej wierności mitowi greckiemu w takiej postaci, jaką przekazał Owidiusz w Metamorfozach), lecz wyłącznie jako przedmiot analizy genologicznej: byłaby tekstem scalającym poetykę jednego gatunku znanego staropolskiej wiedzy o poezji (sielanki) oraz pięciu quasi-gatunków przez nią nierozpoznawanych ${ }^{4}$ (antysielanki, romansu i antyromansu, groteski i „groteski oswojonej”)? Oczywiście przedrostek anty- ma tu znaczenie jedynie wskazujące na wewnątrzgatunkowe relacje "niezgodnej zgodności” romansu i groteski, gdyż niepodobna przyjąć, że taki przedrostkowy „znak sprzeciwu” wyraża samoistne statusy owych quasi-gatunków. Należy powtórzyć oraz podkreślić: w kontekście analizy Dafnidy jedynym gatunkiem o pełnoprawnym statusie genologicznym pozostaje (już w swej naturze hybrydowa?!) sielanka $a^{5}$, niższy status jest dany romansowi i grotesce, jeszcze niższy - antysielance i antyromansowi oraz "grotesce oswojonej".

2 M.K. Sarbiewski O poezji doskonałej..., przeł. M. Plezia, oprac. S. Skimina, Zakład Narodowy im. Ossolińskich, Wrocław 1954, s. 236.

3 "I...] pojęcie twórczości sylwicznej jest nader ekspansywne w dzisiejszym literaturoznawstwie (głównie za sprawą książki Ryszarda Nycza Sylwy współczesne, który - nawiązując do dociekań Stefanii Skwarczyńskiej na temat genezy i struktury manuskryptów określanych mianem silva rerum - posłużył się tytułową materią ahistorycznie, mieszając różne zakresy znaczeniowe pojęcia "sylwa") [...]". R. Krzywy Poezja staropolska wobec genologii retorycznej. Wprowadzenie do problematyki, Wydział Polonistyki UW, Warszawa 2014, s. 11.

4 Jednym z takich gatunków jest np. „sen” (M. Pliszka Wonirycznym teatrze. Sen w poezji polskiego baroku), Uniwersytet Przyrodniczo-Humanistyczny w Siedlcach, Siedlce 2015, s. 161-231 (rozdział Barokowy "sen" jako gatunek literacki).

5 "Ze wszystkich literackich manowców, na które zapuszczają się autorzy, kierowani pokrętną wyobraźnią lub chęcią wykazania się erudycją, mało wiedzie w sposób tak nieunikniony do godnego pożałowania absurdu, jak bukolika". C. Backvis Panorama poezji polskiej okresu baroku, t. 2, red. A. Nowicka-Jeżowa, R. Krzywy, Wydawnictwo Optima JG, Warszawa 2003, s. 103. 
Zarazem jeśli Dafnida będzie interpretowana jako romans, to w trybie nieuniknionym staniemy przed pytaniem o to, jakaż jego odmiana gatunkowa będzie tu przywoływana? Odpowiedź brzmi: miłosno-przygodowa. Zważywszy właśnie hybrydową naturę romansu (ileż jego odmian gatunkowych? niepodobna definitywnie odpowiedzieć), należy podkreślić: $\mathrm{w}$ tym tekście odtąd "romans” (rzeczownik w liczbie pojedynczej) zawsze znaczy ' $\mathrm{r}$ o m a n s mił o s n o - pr zy g o d o wy'. Trudniej ze wskazaniem odmiany gatunkowej sielanki - żadna spośród wyróżnionych przez Annę Krzewińską (ecloga gratulatoria - silviludia, ekloga konsolacyjno-gratulacyjna, ekloga epicedialna, ekloga epitalamijna, ekloga polityczna, ekloga na Boże Narodzenie, sielanki cykliczne ${ }^{6}$ ) nie wydaje się adekwatnym określeniem.

Dafnida faktycznie byłaby gatunkową hybrydą? Przynajmniej wstępnie za twierdzącą odpowiedzią przemawiają te przesłanki, jakimi są głosy badaczy (tu przywołane w porządku rzeczowym, nie zaś chronologicznym). Jan Okoń wprost nazywa ją właśnie „hybrydą”:

Jak [...] określić jednak gatunek Dafnidy? Pozostać by raczej trzeba przy określeniu jej mianem sielanki, przez wzgląd na mieszany charakter tego gatunku i synkretyzm jej form podawc zy ch, przystający zupełnie dobrze do sytuacji w naszym utworze. Uściślić by należało natomiast jej odmianę gatunkową: w swojej [operowej] genezie i formie zewnętrznej łączy się bowiem Dafnis z dramatem, w konstrukcji świata przedstawionego i kompozycji - z epiką. Dla tak powstałej hybrydy bodaj najbardziej adekwatne byłoby miano dialogowanej sielanki epickiej.

Czyż te słowa nie stają się zamknięciem problemu zwerbalizowanego tytułem tego artykułu? Odpowiedź przecząca będzie uzasadniona tym, że hybrydowy status gatunkowy Dafnidy przekracza granice wyznaczane jedynie sielanką i antysielanką, co werbalizuje Janusz K. Goliński: „Owidiuszowemu mitowi o laurowej metamorfozie nadał autor Nadobnej Paskwaliny około roku 1638 hybrydyczną postać gatunkową: i udramatyzowanej si elanki (powołanej do istnienia scenicznym gestem poety), i zmitologizowanego

6 A. Krzewińska Sielanka staropolska. Jej poczq̨tki, tradycje i główne kierunki rozwoju, PWN, Warszawa-Poznań 1979, passim.

7 J. Okoń Wstęp, w: S. Twardowski Dafnis drzewem bobkowym, wstęp, oprac. J. Okoń, Zakład Narodowy im. Ossolińskich, Wrocław 1976, s. LXVIII; podkr. moje - K.O. 
r o m a n s u (zrodzonego z fascynacji epickich pisarza)"8. Z kolei Katarzyna Zimek co prawda o "hybrydzie" wprost nie pisze, ale jednak w jej słowach hybrydyczność Dafnidy pozostaje czymś potencjalnym: „n i e j e d n o r o d ny gat u n k o w o utwór Dafnis drzewem bobkowym (1638), mający formę dialogową, ale pisany strofą poematów epickich - oktawą i nasycony elementami sielanki [... $]^{\prime \prime}$. Na to, że Samuel Twardowski tworzy (ahistorycznie oraz metaforycznie, można powiedzieć) „dzieło otwarte" na wielorakie kwalifikacje gatunkowe, bez niedomówień wskazuje Jan Okoń:

Fakt, że Dafnida wyrosła z kształtującej się jeszcze naówczas opery w sensie i gatunku, i konkretnego utworu z teatru Władysławowskiego jak też $[. .$.$] złożoność świata przedstawionego Dafnidy,$ sprawiają, że określenie jej gatunku nie jest bynajmniej sprawą prostą. W świetle badań dotychczasowych spodziewać się wręcz można odpowiedzi niejednoznacznej. ${ }^{10}$

Taż „odpowiedź niejednoznaczna” brzmiałaby „hybryda”? Wszak Dafnidę można przypisać jednemu znanemu ówczesnej wiedzy o poezji gatunkowi (sielance) i pięciu przez nią nierozpoznawanych quasi-gatunkach (antysielance, romansowi i antyromansowi, grotesce oraz "grotesce oswojonej"). Innymi słowy, w Dafnidzie sielanka zostaje sprzężona zwrotnie z antysielanką, romans - $\mathrm{z}$ antyromansem, groteska zaś - z "groteską oswojoną". Troista dynamika genologiczna...

O sielance oraz o grotesce i o "grotesce oswojonej" można powiedzieć, że są usankcjonowane stanem badań (Jan Okoń; Janusz K. Goliński). Pozostałe trzy quasi-gatunki - antysielanka, romans i antyromans (o tym drugim w kontekście Nadobnej Paskwaliny pisze Paweł Bohuszewicz"11) - powinny zostać dowiedzione analizą Dafnidy.

8 J.K. Goliński „Wnet co za dziwy będq̨ się tu działy...." Groteska oswojona w „Dafnis” Samuela Twardowskiego, w: Wielkopolski Maro. Samuel Twardowski ze Skrzypny i jego dzieło w wielkiej i małej ojczyźnie, red. K. Meller, J. Kowalski, Wydawnictwo „Poznańskie Studia Polonistyczne”, Poznań 2002, s. 238-239; podkr. moje - K.O.

9 K. Zimek Reinterpretacje "Metamorfoz" w poezji polskiego baroku. Narcyz-Akteon - Dafne, Wydawnictwo IBL PAN: Pro Cultura Litteraria, Warszawa 2013, s. 179; podkr. moje - K.O.

10 J. Okoń Wstęp, s. LX; podkr. moje - K.O.

11 P. Bohuszewicz Gramatyka romansu. Polski romans barokowy w perspektywie narratologicznej, Wydawnictwo Naukowe UMK, Toruń 2009, s. 268. 
Już sama kwalifikacja „dialogowana sielanka epicka” wskazuje na genologiczne sprzeczności, które mogą zostać unaocznione tym cytatem:

Formalnie dialogowa, lecz w gruncie rzeczy epicka narracja Dafnidy (postaci również częściowo pełnią funkcje narratora) staje się dalszym wyznacznikiem gatunkowości utworu, po wspomnianej już, epickiej także, kompozycji fabuły oraz budowie świata przedstawionego. To samo powiedzieć można o ukształtowaniu i indywidualizacji postaci: Dafnidy - o jednolitych cechach niezłomnej heroiny, Apollina - o złożonych rysach bohatera e posu rycerskiego (w motywie walki ze smokiem), ro mansu (w głównym wątku utworu) i trage di i (w motywie lauru) $[\ldots] .^{12}$

Te słowa dowodzą, że Dafnida wymyka się jednoznacznym kwalifikacjom genologicznym aż na trzech poziomach: gatunkowym (epos rycerski czy tragedia?) rodzajowym (dramat czy epika?) i najogólniejszym (literatura czy romanse jako, przynajmniej do czasu, nie-literatura?)

\section{Dafnida sielanką i... antysielanką}

Jak przeczytamy w „Argumencie sceny”: „Apollo wygnany z nieba, według poetów, dziewięć lat pasł owce"13. Byłby więc pasterzem - tym samym postacią doprawdy sielankową? Zapytajmy: w jakimże to czasie „dziewięć lat pasł owce”? Jedynie w czasie przedakcji Dafnidy. Kim jest bowiem Apollo w „tu i teraz" świata przedstawionego piórem Twardowskiego? Słonecznym bogiem - co prawda niegdyś ukaranym wcieleniem w pasterza („podłym ludzkim zasłoniony ciałem"), ale po zabiciu smoka Pyto staje się myśliwym. Jego atrybutem już nie jest pasterski kij, lecz łuk i „,sajdak pełnostrzały”. Zarazem w erycyńskiej puszczy napotyka Dafnidę nie jako pasterz szukający powierzonych mu owiec, lecz jako wybawca mieszkańców wiosek, których obronił przed smokiem.

Także tytułowa postać, wodna nimfa, cała oddana polowaniom, w istocie rzeczy nie ma nic wspólnego z wiejskim życiem: rolnictwem czy pasterstwem

12 J. Okoń, Wstęp, s. LXVI; podkr. moje - K.O.

13 S. Twardowski Dafnis drzewem bobkowym, s. 14. Wszystkie cytaty za edycją Jana Okonia (przyp. 7.); w kolejnych cytatach cyfra rzymska oznacza numer sceny, cyfry arabskie - numer oktawy i wersów w oktawie. 
w ogóle się nie para. Dopowiedzmy: w Rzeczpospolitej epoki Twardowskiego polowanie to rycerska powinność w okresach pokoju (jako forma zachowania bitewnej gotowości), a zarazem w stanowej hierarchii społecznej pozostaje ono przypisane szlachcie ${ }^{14}$; wieśniak mógł jedynie kłusować: vide Jan Chryzostom Pasek i przezeń złapany nieszczęśnik z zającem w ręku.

Jeśli nie Apollo i Dafnis, to może postacie Pasterzy współtworzą sielankowy status Dafnidy? Co najwyżej: połowicznie. Pasterska społeczność bowiem wyraźnie dzieli się na dwie grupy. Pierwsza to mężowie i ojcowie ofiar Pyto - w swojej rozpaczy stanowią zaprzeczenie sielankowej aury. Druga to „Pasterze zalotni” - jednak niepodobna o nich ogólnie powiedzieć, że znajdują szczęście w swoich związkach z Pasterkami.

Może więc przynajmniej sceneria będzie sielankowa? Wręcz przeciwnie: co prawda „Pasterze zalotni” najprawdopodobniej dzielą się swoimi miłosnymi doświadczeniami w miejscu faktycznie sielankowym (a z pewnością niedopowiedzianym: wieś? pastwisko?), ale smok Pyto wsie przemienia w „miejsce straszne”, puszcza erycyńska zaś tworzy scenerię wręcz antysielankową, czego dowodzą np. słowa, którymi Apollo wyjaśnia zagubionej Dafnis, w jakim miejscu nieoczekiwanie się spotkali:

Las erycyński to tu nieprzebyty

I nie mieszkane od wieku pustynie,

Gdzie mieszkał Pyto, ludzkich ciał niesyty -

Jeszcze krwią zieją jego dziś jaskinie [...]

VII, 15, 1-4

Tak więc puszcza erycyńska wywołuje przerażenie: dla ludzi nieprzebyta, „miejsce straszne” ${ }^{\text {15 }}$ bez jakichkolwiek „miejsc miłych” (słonecznych

14 „Rozrywką o bardzo dawnym rodowodzie, odwołującą się do rycerskich tradycji szlacheckich, ale także do [...] literackiego wzoru Horacjańskiego [epod Beatus ille qui procul negotiis...] było myślistwo [...]. J.S. Gruchała, S. Grzeszczuk Wstęp, w: Staropolska poezja ziemiańska. Antologia, oprac. J.S. Gruchała, S. Grzeszczuk, PIW, Warszawa 1988, s. 52.

15 „Akcjom przykrym, strasznym, tragicznym towarzyszyły [...] opisy ciemności, pustkowia lub głu sz y le śn ej, ruin, zimnych i ciemnych pieczar oraz skalnych rozpadlin, burzy, pomruków grzmotu, wycia wichru i huku spienionych fal morskich". T. Michałowska Romans XVII i pierwszej połowy XVIII wieku w Polsce. Analiza struktury gatunkowej, w: Problemy literatury staropolskiej, S. I, red. J. Pelc, Wrocław 1972, s. 471; podkr. oryg. - K.O. 
polan, kwiecistych łąk czy skrytych w leśnych ostępach sadów $\left.{ }^{16}\right)$. Zagubionej i zrozpaczonej Dafnis przepastna knieja jawi się jako dwakroć groźna: wręcz wystawia ją na pożarcie przez drapieżną zwierzynę, a zarazem więzi w swoim gąszczu i tym samym sprzyja Apollinowi, pożądającemu dziewicy Diany ${ }^{17}$ - słoneczny bóg jest postrzegany przez Kloryndę niczym męskie zwierzę:

Nie dałaś [Dafnis] ramion, nawet i założyć

Ręki wszetecznej na szyjej różany,

Jako zwykł w trzodzie pienić się i srożyć

Nad jałowicą buhaj rozpasany.

$$
\mathrm{XV}, 14,1-4
$$

Gwałt zostaje skojarzony z męską zwierzęcością i niejako sprzężoną z nią "destrukcją rozumu”18 - tego w sielankowej konwencji nijak pomieścić nie sposób.

Maciej Kazimierz Sarbiewski o poezji bukolicznej pisze: „Jest to rodzaj prawdziwie poetycki, jest bowiem naśladowaniem czynności zaczerpniętych z życia wiejskiego i chłopskiego"19. W jakim zakresie Dafnida pozwala mówić o „naśladowaniu czynności zaczerpniętych z życia wiejskiego i chłopskiego"? Tak dalece ograniczonym, że niepodobna postrzegać jej jako sielankę. Tym bardziej, że metamorfoza Dafnis nie mieści się nawet wśród tak różnorodnych tematów jak te wskazywane dla bukoliki w szkolnych podręcznikach: „vota, gratulacje, pochwały, zazdrość, spory,

16 „[W powieści siedemnastowiecznej] «Miejsce przyjemne» przybierało najczęściej postać leśnej polany (niekiedy też otwartej łą ki). Była ona porośnięta soczystą trawą, pachnącymi kwiatami i ziołami. Jeśli znajdowały się tam drzewa, dawały cień chłodny i przyjemny, ich liście lekko szumiały, a na gałęziach śpiewały ptaki. Niekiedy było słychać szmer strumyka [...]". Tamże, s. 470; podkr. oryg. - K.O.

"[...] przy całym wyrafinowaniu monologów i deklaracji Apollina, przy całej jego niepodważalnej błyskotliwości w operowaniu konwencjonalnym tonem, celem, do którego dąży, jest zaspokojenie potrzeby czysto fizycznej, a zatem niskiej, godnej wzgardy, jak autor pragnie nas o tym przekonać". C. Backvis Panorama poezji polskiej okresu baroku, s. 134.

„Przedstawionej w Dafnidzie potędze zmysłowej miłości, ukazaniu świata «drżącego od namiętności», z «pogańską czcią» dla jego piękna, towarzyszy zupełna destrukcja rozumu, tracącego swe najistotniejsze atrybuty w starciu z namiętnością". G. Raubo Oko i rozum. Myśl antropologiczna w "Nadobnej Paskwalinie"Samuela Twardowskiego, w: Wielkopolski Maro, s. 200. 
napomnienia, obietnice, skargi, radość, śpiewy, wesołość, żarty [...]"20. Któregokolwiek z tych tematów czy choćby czegoś podobnego próżno w Dafnidzie szukać.

Jan Okoń wprost werbalizuje niedookreśloność swej genologicznej kwalifikacji:

he te r o ge ni c z n o ść Dafnidy, jako utworu przynależnego do gatunku sielanki, ma swoje uzasadnienie głębsze, w koncepcji mianowicie świata przedstawionego. Temat, rzecz jasna, zdecydował, że jest on tutaj tworem mocno złożonym i opartym bynajmniej nie tylko na tra d y c y j n i e sielankowym środowisku wiejskim (pomijamy oczywiście kwestię realistycznej wartości opisu), ale też równocześnie - czy raczej: przede wszystkim - wynikającym z wątku i szerokiego tła mitologicznego. ${ }^{21}$

W kontekście tych zdań mniejsza nawet o to, że Anna Krzewińska w monografii opatrzonej tytułem Sielanka staropolska. Jej początki, tradycje i główne kierunki rozwoju przyznaje Dafnidzie status doprawdy marginalny - jest ona postrzegana jedynie w kontekście terminologii genologicznej: to jeden z tych tekstów poezji bukolicznej, które w tytule są pozbawione oznaczenia gatunkowego ${ }^{22}$. Dla antysielanki Twardowskiego niepomiernie ważniejsze będzie co innego...

W świecie przedstawionym Dafnidy do „tradycyjnego sielankowego środowiska wiejskiego" należą jedynie „Pasterze zalotni” - ci jednak są tylko postaciami zaledwie czwartego planu (oczywiście przedstawiony tu podział postaci według planów, na których są usytuowane, będzie subiektywny). $\mathrm{Na}$ pierwszym planie stoją bowiem Apollo i Dafnis; na drugim - Wenus i Kupido oraz Peneusz; na trzecim - „Towarzyszki Dafnidej, Klorynda i Nizyda”; dopiero po nich - postacie czwartego planu: Pasterze. Plan piąty zaludniony jest Trytonami, Nereidami, Nimfami i Najadami. Należy podkreślić: jedyne mocno związane z wiejskim (i poniekąd tym samym sielankowym) środowiskiem postacie to „Pasterze zalotni”, którzy pozostają usytuowani dopiero na czwartym planie. Tak więc w Dafnidzie nawet sielska sceneria pasterskich

20 T. Michałowska Staropolska teoria genologiczna, Zakład Narodowy im. Ossolińskich, Wrocław 1974, s. 148.

21 J. Okoń Wstęp, s. XXXI; podkr. moje - K.O.

A. Krzewińska Sielanka staropolska, s. 76; por. s. 80, 83. 
zalotów sama przez się nie współtworzy sielankowej aury - postaciami najpełniej sielankowymi okazują się wyłącznie Jutrzenka (Prologus sceny, 7, 5-8) oraz Hesperus (Epilog sceny, 3, 1-8).

Po Jutrzence panowanie nad światem przejmuje „Febus złotogrzywy” i tym samym nadchodzi kres sielankowej aury prologu: w „Scenie pierwszej” pojawią się Pasterze z ich „klęską ludzką, którą czynił smok Pyto”. Wschód słońca staje się jakby podniesieniem kurtyny znad ciemności skrywających potwora oraz ogrom tragicznych cierpień jego ofiar. Również zabicie go nie będzie tworzyć czy choćby współtworzyć sielankowej aury, gdyż łuczniczy tryumf słonecznego boga z miejsca rodzi w nim pychę (strzały Apollina przewyższyły gromy samego Jowisza; w porównaniu z nimi czymże strzały Kupido?), ona z kolei wywołuje bezzwłoczną zemstę Wenus. Analogicznie rzecz się ma z Nimfami („nie masz ucieśniejszego na świecie żywota nad myśliwy”) oraz Peneuszem („ciesząc się z pogodnego poranku, wzywa wodnych bogiń, Napeas, żeby mu śpiewały") - tak im, jak i jemu sielankowy żywot kończy się w następstwie spotkania Dafnis i Apollina.

Inną przesłanką, podważającą sielankową kwalifikację Dafnidy, okaże się odpowiedź na pytanie o to, w jakich miejscach dzieje się akcja? Znamienna proporcja: na siedemnaście scen tekstu Dafnidy (prolog + piętnaście scen + epilog) tylko jedna scena piąta („Gromada Pasterzów chwalą Apollina, że zabił smoka") z pewnością wiąże się z tak znamiennie sielankową scenerią, jak pastwisko czy wieś, trzy sceny zaś (pierwsza, czwarta i dziewiąta) - najprawdopodobniej. Tymczasem przepastna puszcza aż dziewięciokrotnie staje się miejscem akcji. To znaczy przynajmniej dwukrotnie częściej niż pastwisko bądź wieś. Co istotne: od sceny dziesiątej aż do ostatniej sceny piętnastej miejscem akcji będzie wyłącznie erycyńska knieja - w chronologicznym porządku świata przedstawionego późniejsze „miejsce straszne” przesłania wcześniejsze „miejsca miłe”.

Jednak wręcz śmiertelnie groźne dla Dafnis górskie odludzie to co prawda istotny, ale tylko jeden z elementów świata wykreowanego piórem Twardowskiego. W podobnej skali (czy może nawet o wiele mocniej) sielankowemu statusowi Dafnidy przeczy doprawdy śmiertelne przerażenie tytułowej postaci, jak też jej intuicyjne przeświadczenie: nimfa przeczuwa, że jest „igraszką ciemnych i przerażających sił"23.

23 C. Backvis Niespodzianki barokowej mitologii: obdarzone skrzelami Napeje Samuela Twardowskiego, w: C. Backvis Renesans i barokw Polsce. Studia o kulturze, wybór i oprac. H. Dziechcińska, E.J. Głębicka, PWN, Warszawa 1993, s. 93. 


\section{Dafnida romansem i... antyromansem}

Czesław Hernas: „W Dafnidzie Twardowski całkowicie pochłonięty jest opowieścią o tragicznej miłości, o bohaterach bezradnych wobec żywiołu"24. Z tego twierdzenia nie wynika bynajmniej, że o dziele Twardowskiego poniekąd siłą rzeczy można mówić jako o romansie - ten wszak jakiegokolwiek monopolu na „opowieść o tragicznej miłości” nie posiada.

Dowodzenie zasadności mówienia o romansie jako o jednej z kwalifikacji gatunkowych Dafnidy początek znajduje w tak mocnej podstawie tekstowej, jak ostatnia oktawa:

Dobrą noc gościom Hesperus powiada,

Dobra noc gościom. Z nieba noc się wali,

Acz kto przy konwi, zorze rad dosiada,

Nie dba, i niebo choć się nań obali,

Szczęśliwy tylko, że nic nie odkłada

Do jutra, ani pyta się o dalej,

A jako puchacz, nie widzi, gdy wschodzi,

Nie widzi słońce i kiedy zachodzi

Epilog sceny, 9, 1-8

Czymże są te słowa? Didaskaliami? Należy odpowiedzieć przecząco, ponieważ z pewnością w żaden sposób nie należą do tekstu pobocznego: nie są jakimikolwiek wskazówkami związanymi z sceniczną realizacją Dafnidy. Ostatnią oktawę poprzedza osiem innych, w których „Hesperus, Wieczorna Gwiazda, wzywa gości do wczasu". Tak więc przychodzi stwierdzić, że to narrator wypowiada się w niej. Ten co prawda sam przez się jeszcze nie rozstrzyga o romansowym statusie Dafnidy, jednak stanowi coś w rodzaju jeśli już nie pomostu, to przynajmniej kładki prowadzącej ku romansowi.

Ilościowy kontrargument, przemawiający przeciwko interpretowaniu ostatniej oktawy jako wypowiedzi narratora, zabrzmi: czymże jest ona w kontekście wszystkich wcześniejszych dwustu siedemdziesięciu czterech oktaw? Rzecz jednak nie w proporcjach ilościowych, lecz w tym, że to jedynie w niej narrator mówi swoim własnym głosem i jej ważności dowodzi (niczym wartość naddana?) finalny status. Taż ostatnia oktawa, nawet jako element skrajnej dysproporcji ilościowej między dialogami i monologami a narracją, wcale nie przekreśla tekstowo realnego statusu narratora. „Opowiadacz” po

C. Hernas Barok, PWN, Warszawa 1998, s. 338; podkr. moje - K.O. 
prostu jest faktem bezdyskusyjnym - jeśli bowiem nie narrator wypowiada się w ostatniej oktawie, to któż inny?! Nikt!

Należy podkreślić: nie tylko pojawianie się, lecz również zanikanie narratora to istotny element romansowej narracji ${ }^{25}$. Paradoksalnie: w Dafnidzie jedynie cząstkowy status narratora (wszak pozostaje kimś konstytuowanym zaledwie jedną oktawą) będzie przeważony finalnym i tym samym nadrzędnym miejscem owej oktawy w linearnym porządku tekstu. Takie wieńczące tekst miejsce „opowiadacza” z jego opowiadaniem pozwala przyjąć, że wszystkie wcześniejsze dialogi oraz monologi są niczym klamrą spięte narracją. Tak więc jeśli „w wielu utworach [współtworzących polski romans barokowy] bezpośrednio przytoczone wypowiedzi stanowią średnio ok. 50\% całego tekstu"26, to Dafnida z jej ogromną przewagą dialogów i monologów, ale jednak nie absolutną ich wyłącznością, może jeszcze mieści się gdzieś na obrzeżu romansowego stanu narracyjnej rzeczy? O Dafnidzie można powiedzieć, że narrator poprzestał na tylko jednej, doprawdy sygnalnej wypowiedzi w ostatniej oktawie. Zarazem w niej pojawia się na tyle wyraziście, że jego istnienia niepodobna zakwestionować. Można nawet odnieść wrażenie, że poniekąd to o nim Iwona Maciejewska pisze te słowa:

opowiadający ujawnia się w tekście raczej sporadycznie, zazwyczaj poprzez wzmiankę narracyjną i to często w jej skrótowej postaci. Taki narrator bardzo rzadko pozwala sobie na wyrażanie własnych sądów i refleksji w danej sprawie, na pouczanie czytelników bądź kreowanych przez siebie bohaterów. Wyjątkowo tylko mówi o sobie „ja”.Tym samym czytelnik traci jego osobę z oczu i nie zastanawia się szczególnie nad tym, kto snuje daną historię. Takiego narratora nazwijmy umownie „ukrytym za świa tem przedstawiony m".

25 „Od tego bowiem, kim jest narrator, jaki związek łączy go z przedstawionym światem, z odbiorcami, z rzeczywistą osobą autora, jaka jest przyjęta przez niego koncepcja narracji, jak jest ustosunkowany do przedmiotu opowiadania, czy tylko o nim opowiada, czy także interpretuje, ocenia, w jaki sposób ukazuje się w dziele lub z a n i ka - od tych przykładowo tu wymienionych [...] problemów zależy nie tylko sens poszczególnych wypowiedzi narratorskich, lecz i charakter przedstawionego w powieści świata". M. Jasińska Narrator w powieści przedromantycznej (1776-1831), PIW, Warszawa 1965, s. 15; podkr. oryg. - K.O.

26 I. Maciejewska Narracja w polskim romansie barokowym, Wydawnictwo UWM, Olsztyn 2001, s. 64 . 
Taką właśnie, tyle że graniczną sytuację mamy w Dafnidzie - to o jej narratorze bez jakichkolwiek zastrzeżeń można powiedzieć: „ukryty za światem przedstawionym". Aż do finalnej oktawy pozostaje kimś, kto z ukrycia obserwuje akcję: niejako schowawszy się za "Argumentem sceny” oraz następującymi po nim dialogami i monologami, inicjalnie nikogo jakkolwiek w cokolwiek nie wprowadza, gdyż od samego początku kryje się w tak głębokim cieniu, że niemal do końca linearnego porządku tekstu będzie niewidzialny na światło wyjdzie dopiero w finalnej oktawie i tym samym dowiedzie, że jego nieobecność to jedynie tymczasowa iluzja.

Przyjmijmy: nawet tylko cząstkowy (gdyż formalnie 'jednooktawowy') narrator może być przesłanką romansowego statusu Dafnidy. Analogicznie rzecz się ma z tzw. objętością. Z jednej strony gdzież bowiem Dafnidzie mierzyć się z takimi romansami jak Kolloander wierny Leonildzie („bez mała 900 stron dużego formatu”) czy Historia Ormunda z Libeina („622 strony zapisanego drobnym maczkiem, miejscami nieczytelnego rękopisu") ${ }^{28}$. Z drugiej strony: „wśród analizowanych [przez Iwonę Maciejewską] romansów są również utwory bardziej oszczędne, tak pod względem rozmiarów, jak liczby oraz stopnia powikłania wątków"29. Tak więc o Dafnidzie w kontekście jej objętości można powiedzieć, że jeszcze mieści się (powiedzmy przez analogię do poziomu rzek) w skrajnie dolnych stanach romansu.

Świat przedstawiony piórem Twardowskiego wyraziściej dowodzi jego romansowego statusu niż stosunkowo skromna tzw. objętość oraz przepastna dysproporcja między dialogami i monologami a narracją finalnej oktawy. Świat przedstawiony - tu należy wskazać przede wszystkim to, co Iwona Maciejewska określa słowami „, bohater w niebezpieczeństwie”, „walka z wrogiem”, ,żywioły”30 . „Bohater w niebezpieczeństwie” - Dafnis (zagrożona miłosnym pożądaniem Apollina oraz zagubieniem się w przepastnej puszczy erycyńskiej). „Walka z wrogiem” - Apollo (strzałą z łuku zabijający Pyto). „Żywioły" - w Dafnidzie doprawdy śmiertelnie groźnym dla zagubionej nimfy jest erycyński las, w istocie zaś przepastna górska puszcza z jej

28 Tamże, s. 14 .

29 Tamże.

„Analiza fabuły interesujących nas utworów pozwala wyodrębnić charakterystyczne grupy motywów, które realizują się w opowiadanej historii poprzez prezentację sceniczną. Dla przykładu wybierzmy z nich kilka, które nazwiemy umownie: «bohater w niebezpieczeństwie», «walka z wrogiem», «żywioły»". Tamże, s. 35. 
drapieżną zwierzyną i - co gorsza - z Appolinem podobnym do „buhaja”. Tak więc trzykrotnie - „bohater w niebezpieczeństwie”, „walka z wrogiem”, „żywioły” - można mówić o adekwatności Dafnidy oraz tego, na co wskazuje autorka Narracji w polskim romansie barokowym.

Zarazem należy podkreślić doprawdy fundamentalne przeciwieństwo między Dafnida a sformułowanym przez Pawła Bohuszewicza schematycznym przebiegiem fabuły w romansie, w którym „Intencja bycia razem” zderza się z „Działaniem Przeciwnika”, które z kolei prowadzi do „Nieudanego//Udanego przeciwdziałania intencji Przeciwnika"31. W owym schematycznym przebiegu fabuły romansu „akcja utworu potoczy się w dwie różne strony, zawsze jednak prowadząc do happy endu, czyli Połączenia Kochanków"32 - Dafnidę wieńczy zaś tragedia, jaką wszak dla obojga pozostanie tytułowa metamorfoza: Dafnis drzewem bobkowym.

Istotnym elementem świata przedstawionego romansu jest znamienna przemienność (już przez Arystotelesa w Poetyce przeciwstawionych) dwóch sytuacji egzystencjalnych bohatera utworu poetyckiego: stanu „szczęścia” i stanu „nieszczęścia”33. Owa przemienność charakteryzuje trzy główne postacie Dafnidy. Przyjąwszy za Teresą Michałowską symbole literowe ( $S$ - stan,,szczęścia”: pomyślności, powodzenia, sprzyjającego układu sytuacji); $L$ - „zmiana losu”; $N$ - stan „nieszczęścia”: niepomyślny układ sytuacji, całkowita klęska, nawet śmierć), ową przemienność losów można przedstawić następująco ${ }^{34}$ :

P. Bohuszewicz Gramatyka romansu, s. 254-255.

Tamże, s. 255 .

T. Michałowska Romans XVII i pierwszej połowy XVIII wieku w Polsce, s. 458; por. s. 461.

„Pokrewieństwo tego schematu [struktury «romansu» hellenistycznego] ze strukturą eposu bohaterskiego uderza bezwzględnie; tym silniej należy więc wyeksponować różnice wiążące sięz «jakością» bohatera oraz podejmowanych przezeń czynności.

Jeśli bowiem bohater eposu klasycznego jest herosem, skupiającym w sobie właściwości postaci «świetnej», «wysokiej» i podejmującym godne siebie akcje [...] - w interesującym nas wariancie [tj. «romansie» hellenistycznym] postacie przedstawione mają rangę etycznie «średnią», a ich działania dotyczą głównie, choć nie wyłącznie, spraw i przeżyć miłosnych, które (przed Dantem) w żadnym razie nie mogłyby pretendować do kategorii czynności «bohaterskich»". Tamże, s. 460 .

W kontekście Etiopik oraz Historii o Chryzeidzie i Arymancie Paweł Bohuszewicz nie tyle podważa, ile problematyzuje ten schemat, dodając coś, co określa jako "romansową ambiwalencję". P. Bohuszewicz, Gramatyka romansu, s. 118-125; 190-201. 
Postacie: Przedakcja: Akcja:

$\begin{array}{lll}\text { Dafnis } & S & S \rightarrow L_{1} \rightarrow N \rightarrow L_{2} \rightarrow S \rightarrow L_{3} \rightarrow N \rightarrow L_{4} \rightarrow S \rightarrow L_{5} \rightarrow N \rightarrow L_{6} \rightarrow S / N \\ \text { Apollo } & S \rightarrow L_{0} \rightarrow N & N \rightarrow L_{1} \rightarrow S \rightarrow L_{2} \rightarrow N \rightarrow L_{3} \rightarrow S \rightarrow L_{4} \rightarrow N / S \\ \text { Peneusz } & S & S \rightarrow L_{1} \rightarrow[N]\end{array}$

Dafnis:

$L_{1}$ - spotyka Apollina

$L_{2}$ - ucieka przed Apollinem

$L_{3}$ - zostaje dogoniona przez Apollina

$L_{4}$ - ponownie ucieka przed Apollinem

$L_{5}$ - prosi Peneusza o schronienie

$L_{6}$ - błaga Dianę o metamorfozę

$S / N$ - finalnie zarazem szczęśliwa (wytrwała w ślubie czystości) i nieszczęśliwa (cnota zostaje ocalona za najwyższą cenę: utraty życia).

Apollo:

$L_{\mathrm{o}}$ - wygnany z Olimpu (ukarany za zabicie cyklopów)

$L_{1}$ - zabija Pyto

$L_{3}$ - napotyka Dafnis

$L_{3}$ - dogania Dafnis

$L_{4}^{3}$ - ponownie dogania Dafnis

N/S - zarazem nieszczęśliwy (utracił Dafnis) i szczęśliwy (wieńce plecione z liści drzewa bobkowego pozostaną wiecznym znakiem jej zacności).

Peneusz:

$L_{1}$ - odrzucenie prośby Dafnis o schronienie przed Apollinem

$[N]$ - po metamorfozie córki rozpacz [uwarunkowana prawdopodobieństwem równym pewności?].

Daremnie uciekając, Dafnis z czasem powie o samej sobie:

I tak, gdzie stąpię, z której pojźrzę strony, Upornym dotąd nieszczęściem miotana, Znikąd pociechy nie mam i obrony,

Strapiona dziewka, dziewka opłakana [...].

$$
\text { XIV, 1, 1-4 }
$$

„Upornym dotąd nieszczęściem miotana” - znaczenie tych słów uwarunkowane jest przemiennością uciekania przed boskim „buhajem” i doganiania. Analogicznie przemienny musi być pościg Apollina. Obydwoje współtworzą 
wieloraką relację „niezgodnej zgodności”, zwieńczoną tragicznym końcem: będą zarazem szczęśliwi i nieszczęśliwi, tyle że najprawdopodobniej w przeciwnych proporcjach (o ile ich emocje, rzecz jasna, mogą być jakkolwiek mierzalne).

W każdym razie jedno wydaje się poza dyskusją: ucieczka Dafnis przed Apollinem jedynie połowicznie pozwala mówić o takiej przemienności stanu „szczęścia” i stanu „nieszczęścia”, jaka była znamienna już dla romansu hellenistycznego. To znaczy: rzecz romansowa zawiera się nie w samych liczbach przemian losu, lecz w tym, że w romansie hellenistycznym bohaterowi, przez kolejne zmiany losu przerzucanemu ze stanu „szczęścia” w stan „nieszczęścia” - i przeciwnie, finalnie zostawało dane to, co można zwerbalizować jako „końcowy, ostateczny stan pomyślności”35. Akurat wręcz odwrotnie w Dafnidzie: z pewnością przemienne losy pary głównych postaci są zwieńczone tragicznie. A więc: antyromans?

Tytułowa postać - Dafnis - jawi się jako „niezgodnie zgodna”. Z jednej strony: „w romansie wymodelowana zgodnie z konwencjami typu «amantki» bohaterka wysuwa się na czoło albo też zajmuje miejsce równorzędne z bohaterem «amantem»" ${ }^{36}$.Z drugiej strony: nawet jeśli w historii wodnej nimfy i słonecznego boga to Dafnis należy przyznać status najważniejszej postaci, przecież nie będzie ona „amantką", lecz jej absolutnym zaprzeczeniem - jawi się jako przepołowiona czy też raczej rozdwojona: współtworzy i romansową więź (jest kochana), i antyromansową (nie chce ani kochać, ani być kochaną).

Za tym, że Dafnida jest antyromansem, przemawia - między innymi porównanie jej fabuły z podstawowym schematem fabuły romansu sentymentalnego (miłosno-przygodowego) ${ }^{37}$. Oto bowiem okaże się, że jego wynikiem będzie sekwencja fundamentalnych sprzeczności (poniżej: schemat owej fabuły przeciwstawiony Dafnidzie):

- dwie młode osoby odmiennej płci spotykają się, od pierwszego spojrzenia rodzi się miłosne uczucie, dochodzi do wyznań, niekiedy nawet do

T. Michałowska Romans XVII i pierwszej połowy XVIII wieku w Polsce, s. 460.

Tamże, s. 481.

Tamże, s. 462. Książka Pawła Bohuszewicza Gramatyka romansu jest poprawioną wersją jego rozprawy doktorskiej, jako powołany w doktorskiej procedurze recenzent Janusz K. Goliński zasadnie zauważa, że słowo "sentymentalny" nie jest trafnym określeniem odmiany gatunkowej ze względu na skojarzenia z późniejszym sentymentalizmem, toteż proponuje, aby mówić o odmianie "miłosno-przygodowej", co przyjmuje Paweł Bohuszewicz, a za nim autor tego artykułu. 
przysięgi miłosnej $\leftrightarrow$ z tego wszystkiego w Dafnidzie pozostaje wyłącznie młody wiek oraz odmienna płeć, natomiast pierwsze spojrzenia wywołują pożądanie i (!) wrogość, wyznaniu miłości zaś przeciwstawia się odrzucenie jej;

- para jest rozdzielana w następstwie niesprzyjających okoliczności nie jakakolwiek siła zewnętrzna (zakaz rodzicielski, waśń rodów czy przeciwdziałania rywala/wroga) staje się przyczyną ucieczki Dafnis przed Apollinem, lecz siła wewnętrzna (ślub dziewicy Diany będzie przeszkodą faktycznie nieprzemożoną);

- każde z zakochanych przeżywa liczne przygody na lądzie i morzu jedyną przygodą Dafnis i Apollina jest (tylko pozornie) przypadkowe spotkanie w puszczy i dramatyczna gonitwa, natomiast nie będzie dana im żadna spośród schematycznych przygód (np. burza i rozbicie okrętu czy znalezienie się w niewoli); wręcz przeciwnie: ucieczka nimfy i pościg słonecznego boga z ich psychologicznie uwarunkowaną logicznością wydają się zaprzeczeniem przygody pojmowanej jako coś zaskakującego;

- wbrew wszelkim niesprzyjającym okolicznościom obie strony szukają się $\leftrightarrow$ jedynie Apollo szuka Dafnis, ta zaś doprawdy panicznie ucieka przed nim;

- następuje spotkanie się zakochanych i definitywne połączenie finalne dogonienie Dafnis oznacza tragiczne zwieńczenie pościgu.

Jakaż relacja wyłania się z tego porównania fabuły Dafnidy z podstawowym schematem fabuły romansu sentymentalnego (tj. miłosno-przygodowego)? Najkrócej: „niezgodna zgodność”. Okazuje się bowiem, że Twardowski podejmuje ów schemat po to, aby zanegować go. Problem jednak polega na tym, że ówcześnie negacja gatunkowej konwencji staje się czymś właśnie konwencjonalnym $^{38}$ ! W wierszowanej odmianie staropolskiego romansu można bowiem zauważyć funkcjonowanie schematu fabularnego niezawierającego

38 „Porównując wierszowaną i prozaiczną odmianę staropolskiego romansu dostrzegamy wszakże, iż druga, będąc dość wiernym odbiciem roman regulier, w znacznie większym stopniu zbliżała się do «idealnego», sentymentalnego wzorca fabularnego. W odmianie wierszowanej natomiast obserwujemy wyraźną skłonność do wyłamywania się spod tradycyjnych, konwencjonalnych schematów: dotyczy to głównie utworów powstających około połowy XVII w. i, dość wyjątkowo, w pierwszej połowie następnego stulecia. Zjawisko to nie było, jak można by z pozoru sądzić, rezultatem indywidualnych decyzji artystycznych poszczególnych autorów. Zbieżność wielu «odchyleń» od wzorca w różnych utworach wyklucza zarówno tę możliwość, jak i ewentualność przypadku; sygnalizuje, że mamy do czynienia ze zjawiskiem systemowym i pozaindywidualnym". T. Michałowska Romans XVII i pierwszej połowy XVIII wieku w Polsce, s. $473-474$. 
"szczęśliwego zakończenia"39. Tak więc tragiczne zwieńczenie losów pary głównych postaci Dafnidy poniekąd unieważnia klasyczną logikę, jest bowiem zarazem schematyczne i antyschematyczne.

Obok zaprzeczenia schematycznemu przebiegowi fabuły w romansie drugą podstawową przesłanką, wskazującą na antyromansowy status Dafnidy, są stany emocjonalne pary głównych postaci, stany te bowiem w znikomym zakresie łączą się z tym, co jest określone następująco: Miłość jako choroba; Tęsknota miłosna; Łzy; Broczenie krwią z miłości; Podejrzenie o zdradę ${ }^{40}$. Jakże niewiele z tego jest dane wodnej nimfie oraz słonecznemu bogu: jeśli łzy, to jedynie zrozpaczonego metamorfozą Dafnis Apollina; o zbliżonych do choroby przejawach uczucia miłosnego żadne z nich doprawdy mówić nie pozwala (ona pozostaje absolutnie odporna na jakiekolwiek pozytywne emocje; on zaś w pełni witalnych sił ściga po puszczańskich bezdrożach tę, której pożąda); można nawet powiedzieć, że ich znajomość trwa zbyt krótko, aby w Apollinie mogły rozwinąć się symptomy miłosnej choroby (tęsknota za Dafnis będzie mu dana dopiero w czasie poakcji); niepodobna nawet pomyśleć o jakimkolwiek broczeniu krwią pod wpływem przeżycia, jakim staje się widok Dafnis Apollo natomiast dumnie wskazuje na łuk i kołczan; również tak romansowe stany emocjonalne jak posądzenie o niewierność czy gwałtowna zazdrość w erycyńskiej puszczy jawią się jako doprawdy niedorzeczne.

Tak więc Twardowski podejmuje aksjomat romansu (dwie postacie odmiennej płci) po to, aby mu zaprzeczyć, wszak o jakiejkolwiek wzajemności uczuć niepodobna mówić. Jeśli w romansie „Miłość jest dominantą psychiki i podstawowym wyznacznikiem postępowania bohatera"41, to o Dafnis można powiedzieć, że ślub dziewictwa i ołowiana strzała syna Wenus swoimi połączonymi siłami czynią z niej antyamantkę.

\section{Dafnida groteską i „groteską oswojoną"}

Powtórzmy: jako sielanka Dafnida okazuje się dwoista, tzn. w ograniczonym zakresie respektuje jej poetykę, a zarazem istotnie przeciwstawia się jej; analogicznie rzecz się ma z romansem - zarazem jest i nie jest nim. W tak hybrydowym

Tamże, s. 474.

Ich katalog: tamże, s. 478.

41 Tamże, s. 479; w kontekście zacytowanego twierdzenia Teresa Michałowska nie wskazuje żadnej odmiany gatunkowej romansu, jednak można przyjąć, że odnosi się ono przede wszystkim właśnie do romansu miłosno-przygodowego. 
stanie genologicznej rzeczy czymś niejako naturalnym będzie skierowanie uwagi w stronę groteski - już w swojej gatunkowej naturze właśnie hybrydowej.

W XVI stuleciu terminem "groteska" poczęto określać mixta composita pojawiające się jako ornamenty dekoracyjne w rzeźbie, architekturze, malarstwie i piśmiennictwie. [...] Wiek XVII zdawał się sprzyjać przekonaniu, że groteska istniała zawsze jako zjawisko w naturze (antyteza rzeczywistości) oraz jako forma w sztuce (opozycja wobec konwencji). [...] Wedle dawnych teoretyków, groteska - charakteryzująca się konceptualnym łączeniem w jednym obrazie, scenie, dziele elementów heterogenicznych, niewspółmiernych - żywi się tym, co roznieca ognie wyobraźni: niejednorodnością i wieloznacznością wyobrażeń, zawikłaniem i burzeniem stereotypów wyobraźniowych. [...]

Lektura - nawet bardzo pobieżna - pozwala stwierdzić, że w świecie przedstawionym Dafnis pojawiają się „klasyczne” postacie groteskowe, że przestrzeń i czas wzięły we władanie mityczne hy b rydy - stwory człeko-, zwierzo- i roślinokształtne. [...] „Zniknięciu” świata oraz „zgęstnieniu" czasu i przestrzeni towarzyszy obezwładniająca trwoga i jej projekcje, bestie i dziwotwory. Wszystkiemu patronują groteskowo upozowane trzy Mojry-Parki: Atropos, Kloto i Lachesis - córy Nocy i boginie przeznaczenia z nicią, wrzecionem i nożycami jako atrybutami $[\ldots] .^{42}$

Nie miejsce tu, aby szerzej przedstawić analizę Janusza K. Golińskiego, wskazującą na to, że Dafnida jest "groteską oswojoną". Toteż jedynie najkrócej: groteskowa fantastyka zawiera się w mitycznych hybrydach (stworach człeko-, zwierzo- i roślinopodobnych) oraz przemianie nimfy w laur, XVII-wieczne zaś „oswojenie” starożytności sprawia, że groteskowość jest estetycznie i emocjonalnie stonowana.

Zarazem do analizy Janusza K. Golińskiego można dopowiedzieć to, co pisze autor Poczucia piękna George Santayana o groteskowych formach plastycznych i stworach człeko-, zwierzo- i roślinopodobnych:

Jego [„typu idealnego, w którym jeden z jego elementów zostaje wyolbrzymiony lub on sam łączy się z innym typem"] rzeczywista doskonałość, podobnie jak doskonałość wszelkiej fikcji, polega na przetworzeniu,

42 J.K. Goliński „Wnet co za dziwy będq̨ się tu działy...", s. 236-237; 239-240; podkr. moje - K.O. 
na uformowaniu rzeczy, której natura nie stworzyła, ale którą można sobie wyobrazić. ${ }^{43}$

Ten sam autor o grotesce jako gatunku konstytuowanym procesem czytelniczego oswajania:

Centaur i satyr przestają być groteskowi, ich typ zostaje zaakceptowany. [...] Dopóki jednak nowy przedmiot na tyle nie odciśnie swej formy w naszej wyobraźni, że możemy uchwycić jego jedność i proporcje, wydaje się nam on złożeniem i zniekształceniem innych form. Jeśli ten chaos jest zupełny, przedmiot jest po prostu niczym; pod względem estetycznym dany jest jedynie jego materiał. Jeśli jednak ów nieład nie jest absolutny, my zaś pomimo dziwaczności formy podejrzewamy istnienie jego jedności i własnego charakteru, zjawia się przed nami groteska. Stanowi ona coś na poły uformowanego, pomieszanego i sugestywnie monstrualnego. ${ }^{44}$

Tak właśnie, oczywiście w przybliżeniu, rzecz się ma z groteskowymi postaciami Dafnidy - zachowują „jedność i proporcje”. Wyróżnia się Peneusz: z jednej strony pozwala mówić o „dziwaczności formy”, z drugiej zaś „,jedności i własnego charakteru" odmówić mu niepodobna. Przyjąwszy Santayany koncepcję groteski (pojmowanej jako stan połowiczny między odrzuceniem chaosu i akceptacją spójności groteskowych wyobrażeń), szczególnie o ojcu Dafnis można powiedzieć, że jest postacią groteskową (nie w pejoratywnym znaczeniu!).

Chrystianizacja pogańskiej wszak mitologii (vide formuła anima naturaliter christiana - dusza z natury [ludzkiej] chrześcijańska) wydaje się tą siłą, która sprawia, że przemiana Dafnis co najwyżej w znikomym zakresie pozostaje groteskowa - jest wszak już dwakroć „oswojona”: greckimi mitami (interpretowanymi jako pogański wyraz chrześcijańskiego Objawienia) i katolickim kultem dziewiczej czystości. Innymi słowy, kiedy działania Apollina i Dafnis współtworzą splot doprawdy tragiczny, wówczas metamorfoza nimfy w drzewo bobkowe okazuje się rozwiązaniem „oswojonym" działaniem dwóch ówcześnie połączonych sił, jakimi pozostają tradycja klasyczna i wiara katolicka (pars pro toto: Maciej Kazimierz Sarbiewski i Dii gentium). Toteż w Dafnidzie o grotesce można mówić jedynie w bardzo ograniczonym zakresie. 


\section{Dafnida gatunkową hybrydą...}

Narrator ujawnia się dopiero w ostatniej oktawie - to znamienne, ponieważ:

Wstęp i z a ko ń c z e n i e, zazwyczaj płynnie wtapiające się w tekst, najsilniej wnoszą do lektury sugestię, że mobilność prezentowanego właśnie dzieła polega na zdolności do absorbowania różnorodnych typów wypowiedzi i narracji, że jest ono formą podatną na mnogość intertekstualnych napięć, a w konsekwencji - na grę nieograniczonej semiozy i wielość lekturowych aktualizacji..$^{45}$

Faktycznie, w Dafnidzie "grają" tak wielorakie wypowiedzi, jak didaskalia oraz dominujące nad 'jednooktawowym' opowiadaniem dialogi i monologi. Zarazem ta wieloelementowa "gra" zostaje sprzężona zwrotnie z "grą" jednego gatunku (sielanki) i pięciu quasi-gatunków (antysielanki, romansu i antyromansu, groteski oraz „groteski oswojonej”). Wyłącznie sielanka swój pełnoprawny gatunkowy status potwierdza ówczesną wiedzą o poezji - pozostałe quasi-gatunki równać się z nią nie mogą. To jednak wcale automatycznie nie przekreśla czytania Dafnidy w perspektywie stanowionej poetyką tekstowych hybryd.

Tak więc na trzech różnych fundamentach (sielankowym, romansowym i groteskowym) Twardowski buduje trzy odmienne budowle (antysielankę, antyromans oraz "groteskę oswojoną"). Jest konstruktorem takiej Dafnidy, której hybrydyczną strukturę gatunkową można unaocznić tym schematem:

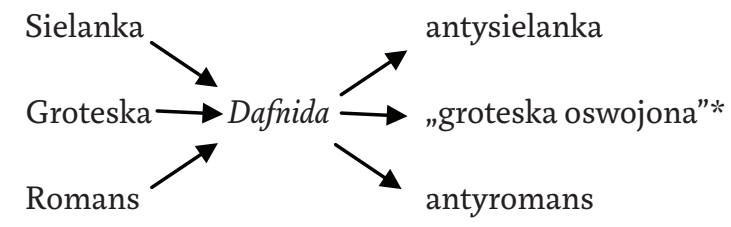

* Przetwarzanie groteski w "groteskę oswojoną" wydaje się procesem genologicznie słabszym niż dwa pozostałe, stąd miejsce pośrodku (groteska gatunkiem czy jedynie formą obrazowania?).

45 M. Lalak Hybrydyzacja narracji jako sposób na czytelnika, w: Formy i strategie wypowiedzi narracyjnej, red. C. Niedzielski, J. Speina, Wydawnictwo UMK, Toruń 1993, s. 166; podkr. moje - K.O. 
Innymi słowy: Twardowski wielorako podejmuje i zarazem podważa konwencje gatunkowe sielanki, romansu i groteski, toteż Dafnida może jawić się jako tekst „otwarty" na "gry” z tymiż konwencjami. Trudno czy może raczej niepodobna rozstrzygnąć, w jakim zakresie hybrydowa Dafnida jest uwarunkowana znamienną dla wierszowanej odmiany romansów „skłonnością do wyłamywania się spod tradycyjnych, konwencjonalnych schematów"46, w jakim zaś wiąże się z poetycką indywidualnością Twardowskiego - nieprzypadkowo wszak zwanego „polskim Maronem"47.

Hybrydowy status Dafnidy może być finalnie dowiedziony przywołaniem tego twierdzenia: „Hybrydy bywają więc polimorficzne, politematyczne i polifunkcyjne" ${ }^{\text {48 }}$. Tak właśnie rzecz się ma w dziele Twardowskiego:

- polimorfizm: jeden gatunek o ówcześnie pełnoprawnym statusie plus pięć jedynie quasi-gatunków;

- politematyczność: pogański mit Dafnis drzewkiem bobkowym jako materia chrześcijańskiego problemu zwerbalizowanego pytaniem Dlaczego dziewictwo jest lepsze niż matżeństwo? ${ }^{49}$;

- polifunkcyjność: „konew” z finalnej oktawy jako to, co można pojmować niczym „,autorskie votum separatum wobec oficjalnie dominującej hierarchii wartości"50.

Tejże polifunkcyjności Dafnidy pośrednio (przez analogię?) dowodzi Nadobna Paskwalina: Twardowski moralizator erotyczne piękno ciała tytułowej bohaterki przewyższy chrześcijańskimi wartościami duchowymi - zarazem Twardowski mężczyzna nie będzie w stanie skryć swej grzesznej fascynacji owym ciałem...

Czy faktycznie Dafnidę z 1638 roku można czytać jako gatunkową hybrydę i tym samym mówić o rozpoznanej w połowie XX wieku „zagładzie

46 T. Michałowska Romans XVII i pierwszej połowy XVIII wieku w Polsce, s. 473-474.

47 Wielkopolski Maro (tamże rozdział drugi jest opatrzony tytułem Sztuka pisarska „polskiego Marona").

G. Grochowski Tekstowe hybrydy. Literackość i jej pogranicza, Wydawnictwo Naukowe UMK, Toruń 2014, S. 266.

49 P. Nehring Dlaczego dziewictwo jest lepsze niż małżeństwo? Spór o ideał w chrześcijaństwie zachodnim końca IV wieku w relacji Ambrożego, Hieronima i Augustyna, Wydawnictwo Naukowe UMK, Toruń 2005. powiedzi w większości wypadków wiąże się autorskie votum separatum wobec oficjalnie dominującej hierarchii wartości - choć tu mogą wchodzić w rachubę porządki o różnym zakresie ważności [...]". G. Grochowski Tekstowe hybrydy, s. 274. 
gatunków"? Zasadnicza część twierdzącej odpowiedzi zawiera się w powyższej części tego artykułu, zarazem pozostają jeszcze dwa dopowiedzenia: biograficzne i teoretycznoliterackie.

Twardowski kształcił się w kaliskim kolegium jezuitów - ówcześnie jednym z najlepszych w całej Rzeczpospolitej (znamienne: niedalekie kolegium poznańskie aspirowało do miana „akademii”). Zakon Ignacego Loyoli wychowywał młodzież zdolną do aktywnego udziału w poszkolnym życiu - jako mówców, a także pisarzy czy nawet dyplomatów. Niejako siłą ówczesnej rzeczy kulturowej warunkiem koniecznym przekonywających wypowiedzi pozostawała biegłość w posługiwaniu się innymi wcześniejszymi wypowiedziami - autorów wielorako autorytatywnych. Zarazem wiedza o gatunkach pozostawała obowiązkowym elementem kompetencji czytelniczej społeczności, oceniającej utwory literackie również czy też przede wszystkim w aspekcie ich zgodności z przyswajanymi w szkolnej edukacji normami gatunkowymi, a w kontekście staropolskiej kultury literackiej o „oryginalności” można mówić jedynie w swoistym znaczeniu tego słowa - ta bowiem miała być dana wyłącznie najwybitniejszym poetom greckim, którzy niejako siłą rzeczy nie mogli czegokolwiek imitować, gdyż po jakiekolwiek wzory literackie sięgać nie mieli gdzie. Toteż o humanistycznej erudycji Twardowskiego Jan Okoń pisze: „pamięciowa, a przy tym konwencjonalna, związana z barokową topiką i wykorzystywaniem po wielokroć tych samych motywów i obrazów, a więc i z "poetyką" (czy raczej techniką?) autopowtórzeń" samym poznawczo co gorsza: „barokowa topika” i postmodernizm współtworzą relację, którą należy określić jako wyjaśnianie nieznanego przez nieznane.

Jeśli w słynnej książce Maurice’a Blanchota Le livre à venir z 1959 roku mowa o „likwidacji” gatunków w europejskiej literaturze nowożytnej (najogólniej: żywe dzieła literackie wręcz rozrywają sieci genologicznych taksonomii), to przecież tak właśnie rzecz się miała z Dafnis z 1638 roku: jeden gatunek (sielanka) i pięć quasi-gatunków współtworzyło to, co można określić słowami unitas et varietas. Innymi słowy, w dziele Twardowskiego mamy taki stan genologicznej rzeczy, o jakim Stanisław Balbus pisze następująco:

Gatunki znikają, ale gatunki powstają i trwają. Ciągle, z każdym nowym utworem i w każdym nowym utworze. Odnosi się wrażenie, że nie one mają kłopot z własnymi bezgatunkowymi (a więc jakby z nieprawego

51 J. Okoń O sztuce poetyckiej Samuela Twardowskiego, w: Wielkopolski Maro, s. 66. 
łoża) narodzinami. I nie ich rodzic - autor. Kłopot należy dopiero do (profesjonalnych) odbiorców. ${ }^{52}$

Co z tego wynika? Mniejsza o twierdzenie w swojej oczywistości może nawet banalne: już sama Dafnida dowodzi, że literatura staropolska pozostaje otwarta na to, co przynosi (mniej lub bardziej) współczesna teoria literatury. Ważniejszy będzie nakaz pogłębiania poszukiwań odpowiedzi na inne pytanie: czy w wymiarze genologicznym pojedynczemu utworowi, jakim przynajmniej dotychczas pozostaje oryginalna w swojej wielorakiej genologicznej tożsamości Dafnida, może być przyznana samoistna kwalifikacja gatunkowa? Przyjąwszy, że świat staropolskich tekstów jest już na tyle rozpoznany, aby odważyć się na twierdzącą odpowiedź, staniemy przed kolejną trudnością - jakim słowem czy też słowami nazwać tenże 'jednotekstowy' gatunek? Najprostsza, acz niestosowna w retorycznym znaczeniu słowa decorum, byłaby „imitacja” jednego z haseł współczesnej reklamy: zamiast „dwa w jednym” - „sześć w jednym”. To jednak silniej zaciemniłoby Dafnidę, niż ją rozjaśniło, a dla wiedzy o literaturze byłoby terminologiczną autodegradacją.

W Polsce zakorzeniła się sformułowana przez Ryszarda Nycza koncepcja "sylwiczności”, o której Stanisław Balbus pisze: „idąca bodaj najdalej, a nietracąca przy tym z oczu genologicznej tradycji”"53. Dla „sylw współczesnych" można jednak wskazać a l te r n a t y w n ą tradycję - byłby nią „rodzaj mieszany" Diomedesa. Ten rzymski gramatyk z IV wieku w dziele Ars grammatica ułożył schemat troistego podziału poezji, który do polskiej świadomości teoretycznej przeniknie w XVI i XVII stuleciu ${ }^{54}$. Wyróżnione w tymże schemacie trzy rodzaje to: genus dramaticum vel activum, genus exegeticum vel enarrativum oraz genus mixtum. Ten ostatni może zaskoczyć tym, jak genologiczny porządek rzeczy poniekąd... staje na głowie:

Nazwa genus mixtum konotowała cechę naprzemienności wypowiedzi poety i postaci, przysługującą gatunkom heroica i lyrica oraz wszystkim utworom, którym przysługiwały równocześnie swoiste cechy gatunków heroica i lyrica, a więc takim, jak Iliada, Odyseja, utwory Archilocha

S. Balbus „Zagłada gatunków”, w: Polska genologia literacka, red. D. Ostaszewska, R. Cudak, PWN, Warszawa 2007, s. 158.

53 Tamże, s. 157.

54 T. Michałowska Staropolska teoria genologiczna, s. 48. 
lub Horacego. Treść nazwy gatunkowej była zatem s z e r s z a od treści nazwy rodzajowej. ${ }^{55}$

Tak więc w kontekście tradycji stanowionej Diomedesa gatunkiem mieszanym kojarzone z „zagładą gatunków” przeciwstawienia (powieść - antypowieść; poemat - poemat prozą; wiersz - wiersz wolny; dramat - monodram ${ }^{56}$ ) tym bardziej mogą przedstawiać się jako przyrodzone jeszcze starożytnemu porządkowi genologicznej rzeczy.

W ostatnim zdaniu finalne wyjaśnienie już „tylko” i zarazem „aż” terminologiczne: w tytule tego artykułu nie ma "sylwy” czy "gatunku mieszanego", ponieważ to "hybryda" jawi się jako najbardziej adekwatny termin wobec tego, co metaforycznie jest określane jako „zagłada gatunków”.

\section{Abstract}

\section{Krzysztof Obremski}

NICOLAUS COPERNICUS UNIVERSITY (TORUŃ)

A Hybrid Genre from 1638: Samuel Twardowski's Daphne Transformed into a Laurel Tree

In the pastoral romance 'Daphne Transformed into a Laurel Tree' by the seventeenthcentury Polish poet, diarist, and essayist Samuel Twardowski, the only genre of legitimate status is the bucolic (in itself already a hybrid?); the romance and the grotesque have a lower status, and an even lower status falls to the anti-bucolic, the anti-romance, and the'tamed grotesque'. To put it differently: Twardowski takes up and at the same time subverts, in various ways, the conventions of the bucolic, of the romance and of the grotesque, so that his 'Daphne' can be read as a text that is 'open' to 'games' with those conventions, which in turn allows us to read it as a contribution to 'the annihilation of genres'.

\section{Keywords}

Samuel Twardowski, bucolic, romance, grotesque

55 Tamże, s. 52, por. s. 53; podkr. moje - K.O.

56 Przywołane za: S. Balbus „Zagłada gatunków”, s. 157-158. 